\title{
Seasonality in nutrient content of banana diagnostic leaf
}

\author{
Larissa Grasiela de Arruda Ferreira Costa ${ }^{1}$, Danilo Eduardo Rozane ${ }^{2}$, Sarah de Araújo Silva ${ }^{3}$, \\ Cibelle Tamiris de Oliveira ${ }^{4}$, Levi Godke Faber Pavarin ${ }^{5}$, Silvia Helena Modenese Gorla da Silva ${ }^{6}$
}

Abstract- Banana farming has an important position in Brazilian agricultural production. This position was earned due to the use of cultivation technologies and adequate fertilization made through recommendations of evaluation of foliar analyzes. The objective of this study was to determine the seasonality of the nutritional status of the diagnostic leaf during the development of banana tree. The experiments took place in the city of Sete Barras / SP, with cultivars such as Grande naine and Prata, on summer and winter. It was evaluated the influence of the collection of the diagnostic leaf in the stations, in six seasons during the development of the banana bunch and it was compared with the standard sampling. The values were submitted to analysis of variance, and when the $\mathrm{F}$ was significant, a comparison of means was performed. The sampling stations and the collection stages influence the nutrient behavior in the diagnostic leaf of both varieties, with exceptions for $\mathrm{Mg}$ and $\mathrm{Mn}$. The average levels of nutrients during the collection stages showed no difference among the $1^{\text {st }}, 2^{\text {nd }}, 3^{\text {rd }}$ and $4^{\text {th }}$ (standard). Even for the 'Prata' and Grande Naine banana plants cultivated in the Ribeira Valley, there is no significant alteration in the nutrient content of the foliage among the 1st to 4th stages, allowing an increasing of collection for foliar tissue analysis. Index terms: Musa spp; nutritional assessment; time of sampling.

\section{Sazonalidade no teor de nutrientes na folha diagnóstica de bananeiras}

Corresponding author: danilo.rozane@unesp.br

Received: November 11, 2018 Accepted: May 23, 2019

Copyright: All the contents of this journal, except where otherwise noted, is licensed under a Creative Commons Attribution License.

\section{(cc) $\mathbf{E Y}$}

Resumo - A bananicultura possui destaque na produção agrícola brasileira. Este destaque é alcançado devido ao uso de tecnologias de cultivo e de adubação adequada feita através de recomendações de avaliação de análises foliares. Objetivou-se neste estudo determinar a sazonalidade do estado nutricional da folha diagnóstica, durante o desenvolvimento do cacho da bananeira. Os experimentos foram conduzidos no município de Sete Barras-SP, com as cultivares 'Grande Naine' e 'Prata', no verão e no inverno. Avaliou-se a influência da coleta da folha diagnóstica nas estações, em seis épocas, durante o desenvolvimento do cacho, e comparou-se com a amostragem-padrão. Os valores foram submetidos à análise de variância, e, quando o $\mathrm{F}$ foi significativo, realizou-se comparação de médias. As estações de amostragem e os estádios de coleta influenciaram o comportamento dos nutrientes na folha diagnóstica de ambas as variedades, com exceções para o $\mathrm{Mg}$ e o $\mathrm{Mn}$. Os teores médios dos nutrientes durante os estádios de coleta não apresentaram diferença entre o $1^{\circ}, 2^{\circ}, 3^{\circ}$ e $4^{\circ}$ (padrão). Assim, para as bananeiras 'Prata' e 'Grande Naine', cultivadas no Vale do Ribeira, não há alteração significativa no teor foliar de nutrientes entre os estádios $1^{\circ}$ a $4^{\circ}$, possibilitando a ampliação de coleta para análise de tecido foliar. Termos de indexação: Musa spp; avaliação nutricional; época de amostragem.

\footnotetext{
${ }^{1}$ Agronomic Engineer, Master student, Paraná Federal University (Universidade Federal do Paraná-UFPR)-PR, Brasil. Email: larissagrasielacosta@gmail.com ${ }^{\text {(ORCID 0000-0002-0951-0387) }}$

${ }^{2}$ Associate Professor, University of the State of São Paulo.Registro- SP, Brasil. Scholarship of CNPq. Email:danilo.rozane@unesp.br ${ }^{\text {(ORCID }}$ 0000-0003-0518-3689)

${ }^{3}$ MSc., Paraná Federal University (Universidade Federal do Paraná-UFPR)-PR, Brasil. Email: sarah-araujo-silva@bol.com.br (ORcID 0000-00021840-9416)

${ }^{4}$ MSc., PhD student, Paraná Federal University (Universidade Federal do Paraná-UFPR)-PR, Brasil. Email: cibelleolv@gmail.com ${ }^{(\text {ORCID 0000- }}$ 0002-2957-0969)

${ }^{5}$ Agronomic Engineer, University of the State of São Paulo.Registro-SP, Brasil. Email: levipavarin@gmail.com (ORCID 0000-0003-4639-6867) ${ }^{6}$ PhD Professor, University of the State of São Paulo.Registro-SP-Brasil. Email: silvia.modenese@unesp.br (ORCID0000-0003-0697-9865)
} 


\section{Introduction}

Banana is considered a staple food for millions of people because of its nutritional value and consolidated palatability, being one of the most consumed fruits in the world, cultivated by small and large rural producers, occupy the third position in the world ranking of the most produced fruit, with a production of 106.5 million tones (FAOSTAT, 2018). In 2016, 6.9 million tons of banana were produced in Brazil, in an area of about 517 thousand hectares, indicating a yield of $14.7 \mathrm{t} \mathrm{ha}^{-1}$ (IBGE, 2016).

Despite the largest banana producing states in Brazil (Bahia, São Paulo and Minas Gerais), together produce the largest productions $(43 \%)$ and cultivated area (35\%), Coltro and Karaski (2019) show that the state of Rio Grande do Norte had the highest national productivity (29.8 $\left.\mathrm{t} \mathrm{ha}^{-1}\right)$, while São Paulo presented the fourth highest yield $\left(21.3\right.$ tha $\left.^{-1}\right)$, Minas Gerais the seventh $\left(17.3 \mathrm{t} \mathrm{ha}^{-1}\right)$ and Bahia the eighth $\left(16.1 \mathrm{tha}^{-1}\right)$, which indicates the influence of the local conditions of cultivation, so that better performances are obtained, adapting to the production technologies applied to each region in different genotypes of bananas produced in the country.

Among the techniques used in banana crop production technology, foliar nutritional diagnosis evaluates the nutritional conditions of the plant's mineral nutrition, with the objective of supporting the management of fertilization through the application of variable doses of fertilizers or adequate fertilization to different locations. In banana plants Martin-Prével (1984) demonstrated the importance of foliar analysis for monitoring the nutritional status, establishing the International Reference Sampling Method (Méthode d'Echantillonnage Internationale de Référence - MEIR) which consists of the sampling of the third leaf (f3), counting from the apex, at the time when the inflorescence presents with all the female tiers without bracts and two or three open male tiers, since for the development of their fruits the banana plant depends on the accumulated degree-days (DD), from flowering to harvest period (JULLIEN et al., 2008; CASTELLAN et al., 2018).

For evaluation the method suggests the removal in 20 plants of a central band of leaf $\mathrm{f3}$, with width of 10 $\mathrm{cm}$, eliminating the central rib and the outer halves of the end of these bands.

There is adequate importance to the standardization of leaf sampling, so that reliable comparisons and interpretations can be made to the nutritional standards/ balances established for nutritional evaluation in the banana crop. Martin-Prével (1984), indicates that the best way to sample may differ in practice according to the cultivars, ecological conditions and form of cultivation employed in commercial plantations in Brazil.

Commercial areas of banana plantations cultivated in the tropics or in equatorial regions have fields of 1 to 4 hectares, with plants at all stages of development, which may hamper, at certain times, to find of 20 plants in the specific physiological stage considered adequate by MEIR (MARTIN-PRÉVEL, 1984).

Due to these difficulties, adaptations and local adaptations to the MEIR has been proposed in order to facilitate the collection of the diagnostic leaf and maintain the standard of interpretation. For 'Prata-Anã' cultivated in the north of Minas Gerais, Silva et al. (1999) recommend for foliar diagnosis of banana, sampling according to the MEIR method, adapting it to plants at the beginning of flowering. Rodrigues et al. (2010), report that the 'PrataAnã' banana planted in the north of Minas Gerais presents a high size $(4.4 \pm 0.25 \mathrm{~m})$ and a dense foliar rosette (leaves slightly spaced), which makes it difficult to identify f 3 and collection of the ideal width recommended by MEIR to be sampled. This difficulty led the authors to investigate the pattern and to suggest that leaf collection in the above (f2) or below (f4) position of the recommended leaf (f3), in a leaf width of 10 to $30 \mathrm{~cm}$, does not alter the leaf contents in relation to the MEIR method. Such tolerances in the variation of the sample regarding the position and leaf width, in the harvest of the diagnostic leaf, can provide agility and greater reliability.

Another point that has raised doubts, so that there is flexibility in the evaluation process of nutritional diagnosis, without damages to the MEIR standard, refers to the harvesting season of leaf $\mathrm{f} 3$. In order to know the best season, Rodrigues et al. (2010) evaluated 'Prata-Anã' bananas plants when it was possible to visualize all the tiers and fruits (female flowers), which happens when the first tires begin to open. Godoy et al. (2011), although did not evaluate the effect, carried out the foliar sampling in 'Nanica' and 'Prata' banana plants when the plants began to emit the bunch. Silva and Rodrigues (2001) in bananas orchards from the north of Minas Gerais evaluated the leaves when the inflorescence was in the intermediate stage between their emission and at the maximum with all the female tires opened.

For clarification on the subject it was aimed, in this study, to determine in commercial fields of two banana cultivars, Grande Naine and Prata, in two evaluation stations, the seasonality of the nutritional status of the diagnostic leaf, during the development of the bunch.

\section{Material and methods}

The experiments were conducted in commercial fields of 5 ha of cultivar Grande Naine and Prata and 'Prata' banana plants, both with 10 years of cultivation, not irrigated, with a density of 2,500 and 1,600 plants, and average productivity of 35 and 22 tons per hectare, respectively. They are located on the banks of the Ribeira de Iguape river and represent one of the most traditional banana cultivation sites in this region, in the municipality 
of Sete Barras, southern region of the state of São Paulo, where banana farming has 33,561 hectares (IEA, 2018) of planted area. The climate, based on the Köppen system, is classified as Af, tropical humid, the average rainfall is $1,600 \mathrm{~mm} /$ year.

The fertility of the experimental areas was evaluated by the collection of 20 simple subsamples of soil, in the banana fertilization region at depths of 0.0 0.2 and 0.2-0.4 m, which comprised a composite sample which was analyzed according to Raij et al. (2001), whose results are shown in Table 1 . The areas where the study was carried out prior to the implantation of the current fields were being cultivated with Grande Naine banana plants, and the current management practices followed the local indications of cultivation, indicated by Moreira (1987), emphasizing that the control of black Sigatoka was carried out in a preventive way, with aerial applications of fungicides.

The experimental designs used for both experiments were completely randomized, with three replications, in a $2 \times 6$ factorial scheme, being the winter and summer time of the year, the plots. For the 'Grande Naine' the summer drought period - corresponded to the period from February to May 2015 and the winter period - rainy period - from June to October 2015, and for 'Prata' the winter period - rainy period - corresponded from August to December 2014 and the summer period - drought period - the months of February to June 2015.

The secondary factor was constituted of six stages of collection, according to the banana stages: first - when the plants began the emission of the bunch; second - when it was possible to visualize a feminine tire, and fruit (female flowers); third - when viewed three female tiers, and fruits ; fourth - when it was possible to visualize all the female tires and fruits, as well as two open male tires (MEIR standard); fifth - when the bunches had $50 \%$ of their development, that is, half the time for their harvest; and the sixth-in the commercial crop of the bunches, that is, ' $3 / 4$ thin', which corresponds to the time that the fruits of the tire, two still had corner and the last tire had $33 \mathrm{~mm}$ of diameter, corresponding to the degree of maturation.

Each replicate was composed of a sample composed of 20 leaves of plants collected during the summer and winter periods. The collections of stages 1 to 6 , from the emission of the bunch, represent, in the summer and winter seasons in days: 1,$1 ; 8,7 ; 11,15 ; 15,24 ; 65,86$ and 109,127 , respectively for 'Grande Naine', and: 1,$1 ; 8,7 ; 11,15$; 15,$22 ; 109,64$ and 150,112, respectively for the 'Prata'.

The recommendation for leaf type followed the MEIR indication, evaluating the third leaf(f3), with width of $10 \mathrm{~cm}$, eliminating the central rib and the external halves of that strip. The collected plant material was washed and dried in a forced air ventilation oven at $65^{\circ} \mathrm{C}$ until reaching constant weight, ground in a Willey mill and analyzed according to methodology described by Bataglia et al. (1983).

The evaluations in Degrees days were made with the thermal indications of temperature obtained in the network of the Integrated Center of Agrometeorological Information (Centro Integrado de Informações AgrometeorológicasCIIAGRO), and its accumulation after the emission of the bunch, about the first evaluation, was calculated by the equation:

$$
\text { Degree Days }=\sum_{i=1}^{i=n} \max \left(0, \frac{T_{\min (i)+} T_{\max (i)}}{2}-T_{\text {base }}\right)
$$

Where, $\mathrm{T}_{\text {min }}$ and $\mathrm{T}_{\text {max }}$ are respectively the minimum and maximum temperature $\left({ }^{\circ} \mathrm{C}\right)$ on a given day, while $\mathrm{T}_{\text {base }}\left({ }^{\circ} \mathrm{C}\right)$ is the base temperature below which the banana growth ceases. The base temperature was assumed to be $14^{\circ} \mathrm{C}$ according to Robinson (1996), and used by Taulya et al. (2014) carried out with the intention of comparing if the collection period to the plant maturation degree after the emission of the bunch interferes with the amount of nutrient present in $\mathrm{f} 3$ leaf and consequently interfere in the collection sampling period.

The results of the obtained nutrient contents were submitted to analysis of variance with the support of SISVAR software (FERREIRA, 2011), and when the F was significant at $5 \%$, a comparison of means by Tukey's test was performed $(\mathrm{p}<0.05)$.

\section{Results and discussion}

The soil which the experiments were conducted showed medium to high concentrations for banana cultivation (Table 1), according to Raij et al. (1997) classification, which leads us to consider that banana plants were not subjected to nutritional restriction, as observed in Table 1, that indicates the nutrient levels in the soil at the time the experiment was conducted.

The collections of stages 1 to 6 , from the emission of the bunch, represent in the summer and winter seasons in Degrees-days the accumulation of: $18.5 ; 103.38$; $145.73 ; 196.137 ; 737.574$ and 1091.943 respectively for 'Grande Naine', which corroborates with Taulya et al. (2014), that observed for banana plants of 'Nanica' group in Africa, the accumulation of 790 to $1008^{\circ}$ days between the emission and the harvest of the bunch, which represents about $20 \%$ of the accumulated Degrees-days that the banana plants needs to complete their entire development cycle. The experiment with the 'Prata' cultivar presented higher accumulated Degrees-days among the stages 1 to 6 , in the summer and winter seasons, being: $18.8 ; 103.55 ; 145.93 ; 196.146 ; 1091.487$ and 1330 . 1062 , respectively. Variations between the accumulated Degrees-days between cultivars and/or harvesting periods are common, as stated by Fortescue et al. (2011) who observed variations of $46 \%$ in the accumulated Degreesdays, for the complete development (planting to harvest) 
of bananas plants of different species and / or implemented at different periods, in Puerto Rico.

In an experiment conducted in the north of Minas Gerais, Figueiredo et al. (2005) with 'Prata Anã' banana plant in the evaluation with $40 \%$ of the reference evapotranspiration $\left(\mathrm{ET}_{0}\right)$ observed that there was an accumulation of degrees-days of $714^{\circ} \mathrm{C}$ and $472^{\circ} \mathrm{C}$ in the flowering period to the development of the mother plant's bunch, being the lowest treatment, corresponding to the summer and winter months, which shows differences between accumulated degrees-days from the water availability when it is considered that the drought period (summer) accumulates more thermal energy than in the rainy season (winter) during the culture cycle.

It was verified that, in general, the average levels of nutrients in the diagnostic leaf of 'Prata' (Table 3) and 'Grande Naine' (Table 6) banana plants collected at stage 4 , which includes the indication of MEIR, are found below the proper range proposed for banana by Raij et al., (1997), in bulletin 100 for the State of São Paulo.

The only exceptions of suitable contents are observed for both cultivars for $\mathrm{Ca}$ and $\mathrm{Mg}$ (Tables 3 and 6), as well as excessive levels of B for 'Prata' (Table 3) and adequate B and Mn for 'Grande Naine' (Table 6). Although adequate $\mathrm{Ca}$ and $\mathrm{Mg}$ foliar contents for both cultivars, the concentrations observed in the cultivation areas (Tables 2 and 5) of these elements are considered high (RAIJ et al., 1997), which may be inducing competition for absorption between the sites by K (Malavolta, 2006) and inducing low leaf contents.

Sampling stations and collection stages influenced the content of all nutrients in $\mathrm{f3}$ of 'Prata' (Table 4) and 'Grande Naine' (Table 6) banana plants, the only exceptions occur with $\mathrm{Mg}$ and $\mathrm{Mn}$ whose levels were not influenced by the stages and collection seasons, respectively.

Regardless of the evaluated variety and the observed stage, in general, the highest concentrations of nutrients occur in the winter (Tables 4 and 6). A likely explanation may be associated with no water restriction in the period, which allows constant flow of nutrients especially for mass flow, the primary means of conduction nutrients to plants as reported by Malavolta (2006) and Oliveira et al. (2010), in addition, in the winter, there is a greater accumulation of Degrees-days due to the lower incidence of radiation, thus reducing the photosynthetic efficiency of this plant (TAULYA et al., 2014). This allowed greater accumulation of nutrients in the leaves of both varieties observed in Tables 3 and 6; Rozane et al. (2016) indicate that climatic conditions and different periods of harvest of the diagnostic leaf, even though of the same species, provide significant nutritional variations in the nutritional balance of the diagnostic leaf, which ensures that it is reflected in the data of tables 3 and 6 since the nutrients generally tend to migrate to the bunch from stage 4 .

In the evaluation of the nutritional diagnosis, emphasized by Rodrigues et al. (2010), which analyzes in bananas plants the proposal to change the plant tissue sample is valid if the values are not significantly altered compared to the levels determined by the reference procedure, what actually occurred for all nutrients, in any of the collection stations, in the experiments with the 'Prata' (Table 2) and 'Grande Naine' (Table 5) banana plants.

When it is observed that there is no difference between collection stages 1, 2, 3 or 4 , the last characterized by the MEIR standard, in practice for both varieties (Tables 3 and 6), indicates as similar the levels observed in different stages of sampling in the studies of Silva and Rodrigues (2001); Rodrigues et al. (2010) and Godoy et al. (2011), as well as tolerable a possible variation of the sample when it comprises the emission of the bunch at the time when the inflorescence (stage 1 to stage 4) shows all female tiers without bracts and with two or three open male tiers. The expansion of physiological stages without compromising the reference of the nutritional diagnosis evaluation facilitates, according to Martin-Prével, (1987) to locate plants suitable for foliar diagnosis, especially in banana plantations, in a tropical or equatorial area without replanting for several years, in fields smaller than four hectares.

Table 1. Soil chemical analyzes in the experimental areas, at depths of $0.0-0.2 \mathrm{~m}$ and $0.2-0.4 \mathrm{~m}$.

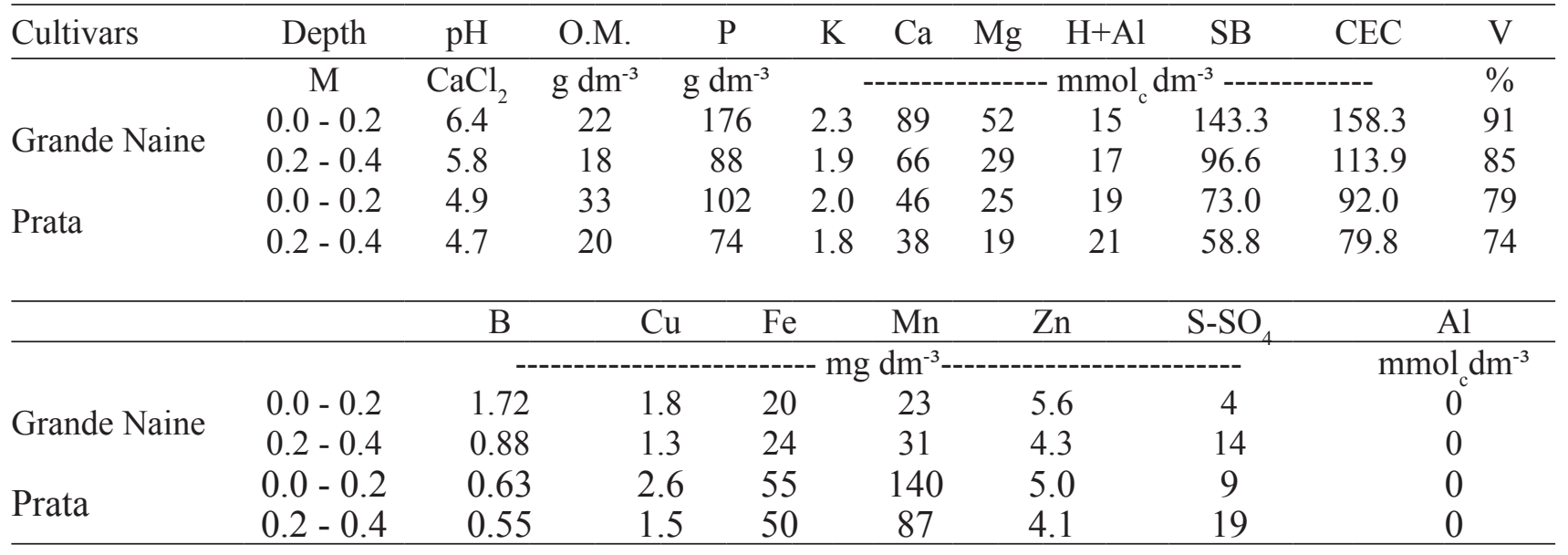


Table 2. Variation of nutrient contents in banana leaves-index 'Prata' banana plant cultivar in two seasons (winter and summer).

\begin{tabular}{ccccc}
\hline \multirow{2}{*}{ Nutrients } & \multicolumn{2}{c}{ Variation } & \multicolumn{3}{c}{ Seasons } \\
\cline { 4 - 5 } & $\mathrm{F}$ & $\mathrm{CV}(\%)$ & Winter & Summer \\
\cline { 4 - 5 } $\mathrm{N}$ & $61.1^{* *}$ & 3.7 & $24 \mathrm{a}$ & (drought period) \\
$\mathrm{P}$ & $6.6^{* *}$ & 5.5 & $1.8 \mathrm{a}$ & $27 \mathrm{~b}$ \\
$\mathrm{~K}$ & $60.1^{* *}$ & 8.3 & $25 \mathrm{a}$ & $1.7 \mathrm{~b}$ \\
$\mathrm{Ca}$ & $24.1^{* *}$ & 9.9 & $9 \mathrm{a}$ & $31 \mathrm{~b}$ \\
$\mathrm{Mg}$ & $1.9^{\mathrm{ns}}$ & 6.8 & $3.4 \mathrm{a}$ & $10.7 \mathrm{~b}$ \\
$\mathrm{~S}$ & $166.4^{* *}$ & 5.0 & $2.0 \mathrm{a}$ & $3.5 \mathrm{a}$ \\
$\mathrm{B}$ & $11.0^{* *}$ & 9.6 & $29.1 \mathrm{~b}$ & $1.5 \mathrm{~b}$ \\
$\mathrm{Cu}$ & $0.04^{\mathrm{ns}}$ & 7.9 & $4.3 \mathrm{a}$ & $26.2 \mathrm{a}$ \\
$\mathrm{Fe}$ & $111.8^{* *}$ & 7.2 & $75 \mathrm{~b}$ & $4.3 \mathrm{a}$ \\
$\mathrm{Mn}$ & $0.4^{\mathrm{ns}}$ & 18.0 & $238 \mathrm{a}$ & $59 \mathrm{a}$ \\
$\mathrm{Zn}$ & $0.01^{\mathrm{ns}}$ & 7.5 & $11.6 \mathrm{a}$ & $228 \mathrm{a}$ \\
\end{tabular}

'Lowercase letters between the seasons by the Tukey test at $p<0.05$. Where, ns, ${ }^{* *},{ }^{*}$ : not significant, significant at $p<0.01$ and 0.05 , respectively. $\mathrm{CV}=$ Coefficient of variation; $\mathrm{F}=$ variation factor value. $\mathrm{g} . \mathrm{Kg}$ for macronutrient; $\mathrm{mg} . \mathrm{kg}$ for micronutrient

Table 3. Variation of nutrient contents in banana leaves-index of 'Prata' banana plant cultivar in six stages of collection.

\begin{tabular}{ccccccccc}
\hline \multirow{2}{*}{ Nutrients } & \multicolumn{2}{c}{ Variation } & \multicolumn{7}{c}{ Stage (Time) } \\
\cline { 3 - 8 } & $\mathrm{F}$ & $\mathrm{CV}(\%)$ & 1 & 2 & 3 & 4 & 5 & 6 \\
\hline $\mathrm{N}$ & $18.1^{* *}$ & 3.7 & $27 \mathrm{C}$ & $27 \mathrm{C}$ & $27 \mathrm{C}$ & $26 \mathrm{BC}$ & $24 \mathrm{AB}$ & $23 \mathrm{~A}$ \\
$\mathrm{P}$ & $20.9^{* *}$ & 5.5 & $2.0 \mathrm{~B}$ & $1.9 \mathrm{~B}$ & $1.8 \mathrm{~B}$ & $1.8 \mathrm{~B}$ & $1.6 \mathrm{~A}$ & $1.4 \mathrm{~A}$ \\
$\mathrm{~K}$ & $5.3^{* *}$ & 8.3 & $28 \mathrm{AB}$ & $26.9 \mathrm{AB}$ & $29.6 \mathrm{~B}$ & $29.5 \mathrm{~B}$ & $24.2 \mathrm{~A}$ & $26.4 \mathrm{AB}$ \\
$\mathrm{Ca}$ & $11.8^{* *}$ & 9.9 & $8.8 \mathrm{AB}$ & $8.0 \mathrm{~A}$ & $9.8 \mathrm{BC}$ & $9.8 \mathrm{BC}$ & $11 \mathrm{CD}$ & $11.8 \mathrm{D}$ \\
$\mathrm{Mg}$ & $1.8^{\text {ns }}$ & 6.8 & $3.5 \mathrm{~A}$ & $3.3 \mathrm{~A}$ & $3.6 \mathrm{~A}$ & $3.4 \mathrm{~A}$ & $3.4 \mathrm{~A}$ & $3.6 \mathrm{~A}$ \\
$\mathrm{~S}$ & $17.3^{* *}$ & 5.0 & $1.9 \mathrm{~B}$ & $1.8 \mathrm{~B}$ & $1.9 \mathrm{~B}$ & $1.8 \mathrm{~B}$ & $1.6 \mathrm{~A}$ & $1.5 \mathrm{~A}$ \\
$\mathrm{~B}$ & $10.3^{* *}$ & 9.6 & $31 \mathrm{C}$ & $31.1 \mathrm{C}$ & $27.6 \mathrm{BC}$ & $28 \mathrm{BC}$ & $21.8 \mathrm{~A}$ & $26.2 \mathrm{AB}$ \\
$\mathrm{Cu}$ & $24.7^{*}$ & 7.9 & $4.5 \mathrm{BC}$ & $4.5 \mathrm{BC}$ & $4.7 \mathrm{BC}$ & $4.1 \mathrm{~B}$ & $2.9 \mathrm{~A}$ & $4.9 \mathrm{C}$ \\
$\mathrm{Fe}$ & $17.4^{* *}$ & 7.2 & $65.1 \mathrm{~A}$ & $61.6 \mathrm{~A}$ & $62.2 \mathrm{~A}$ & $65.7 \mathrm{~A}$ & $63.8 \mathrm{~A}$ & $83.5 \mathrm{~B}$ \\
$\mathrm{Mn}$ & $27.1^{* *}$ & 18.0 & $161.6 \mathrm{~A}$ & $157.6 \mathrm{~A}$ & $209.5 \mathrm{~A}$ & $195.2 \mathrm{~A}$ & $287.1 \mathrm{~B}$ & $387.7 \mathrm{C}$ \\
$\mathrm{Zn}$ & $5.2^{* *}$ & 7.5 & $12.3 \mathrm{~B}$ & $11.9 \mathrm{~B}$ & $12.2 \mathrm{~B}$ & $11.4 \mathrm{AB}$ & $10.2 \mathrm{~A}$ & $12.1 \mathrm{~A}$ \\
\hline
\end{tabular}

${ }^{1}$ Different capital letters differ between the stages by the Tukey test at $\mathrm{p}<0.05$. Where, ${ }^{\mathrm{n}},{ }^{* *}, *$ : not significant, significant at $\mathrm{p}<0.01$ and 0.05 , respectively.CV $=$ Coefficient of variation. g.Kg for macronutrient; mg.kg for micronutrient 
Table 4. Variation of nutrient contents in banana leaves-index in 'Prata' banana plant cultivar in two seasons and six stages of collection.

\begin{tabular}{|c|c|c|c|c|c|c|c|c|c|c|c|}
\hline \multirow[t]{2}{*}{ Nutrients } & \multicolumn{4}{|c|}{ Variation Cause } & \multirow[t]{2}{*}{ Season (s) } & \multicolumn{6}{|c|}{ Stage $(\mathrm{T})$} \\
\hline & Season (S) & Stage $(\mathrm{T})$ & $\mathrm{S} * \mathrm{~T}$ & $\mathrm{CV}$ & & 1 & 2 & 3 & 4 & 5 & 6 \\
\hline \multirow{2}{*}{$\mathrm{N}$} & \multirow{2}{*}{$61.1 * *$} & \multirow{2}{*}{$18.1 * *$} & \multirow{2}{*}{$1.7^{\mathrm{ns}}$} & \multirow{2}{*}{3.7} & Winter & $28 \mathrm{bBC}$ & $28 \mathrm{bC}$ & $28 \mathrm{bC}$ & $28 \mathrm{bBC}$ & $26 \mathrm{bAB}$ & $24 \mathrm{~A}$ \\
\hline & & & & & Summer & $26 \mathrm{aB}$ & $26 \mathrm{aB}$ & $25 \mathrm{aB}$ & $24 \mathrm{aAB}$ & $23 \mathrm{aA}$ & $23 \mathrm{~A}$ \\
\hline \multirow{2}{*}{$\mathrm{P}$} & \multirow{2}{*}{$6.6^{* *}$} & \multirow{2}{*}{$20.9 * *$} & \multirow{2}{*}{$3.4^{* *}$} & \multirow{2}{*}{5.5} & Winter & $2.1 \mathrm{bC}$ & $1.9 \mathrm{bBC}$ & $1.9 \mathrm{BC}$ & $1.8 \mathrm{AB}$ & $1.6 \mathrm{bA}$ & $1.6 \mathrm{~A}$ \\
\hline & & & & & Summer & $1.8 \mathrm{aBC}$ & $1.7 \mathrm{aBC}$ & $1.9 \mathrm{C}$ & $1.8 \mathrm{BC}$ & $1.4 \mathrm{aA}$ & $1.6 \mathrm{AB}$ \\
\hline \multirow{2}{*}{ K } & \multirow{2}{*}{$60.1 * *$} & \multirow{2}{*}{$5.3^{* *}$} & \multirow{2}{*}{$2.7^{*}$} & \multirow{2}{*}{8.3} & Winter & $24 \mathrm{a}$ & $25 \mathrm{a}$ & $24 \mathrm{a}$ & $27 \mathrm{a}$ & 23 & $24 \mathrm{a}$ \\
\hline & & & & & Summer & $32 \mathrm{bBC}$ & $29 \mathrm{bAB}$ & $35 \mathrm{bC}$ & $33 \mathrm{bBC}$ & $25 \mathrm{~A}$ & $29 \mathrm{bAB}$ \\
\hline \multirow{2}{*}{$\mathrm{Ca}$} & \multirow{2}{*}{$24.1 * *$} & \multirow{2}{*}{$11.8 * *$} & \multirow{2}{*}{$0.21^{\mathrm{ns}}$} & \multirow{2}{*}{9.9} & Winter & $8 \mathrm{aAB}$ & $8 \mathrm{~A}$ & $9 \mathrm{ABC}$ & $9 \mathrm{ABC}$ & $10 \mathrm{aBC}$ & $11 \mathrm{aC}$ \\
\hline & & & & & Summer & $10 \mathrm{bAB}$ & $9 \mathrm{~A}$ & $11 \mathrm{ABC}$ & $10 \mathrm{ABC}$ & $12 \mathrm{bBC}$ & $13 b \mathrm{C}$ \\
\hline \multirow{2}{*}{$\mathrm{Mg}$} & \multirow{2}{*}{$1.9^{\text {ns }}$} & \multirow{2}{*}{$1.8^{\mathrm{ns}}$} & \multirow{2}{*}{$7.9^{* *}$} & \multirow{2}{*}{6.8} & Winter & $3.3 \mathrm{~A}$ & $3.2 \mathrm{~A}$ & $3.3 \mathrm{aA}$ & $3.1 \mathrm{aA}$ & $3.6 \mathrm{bAB}$ & $3.9 \mathrm{bB}$ \\
\hline & & & & & Summer & $3.7 \mathrm{AB}$ & $3.4 \mathrm{AB}$ & $3.9 \mathrm{bB}$ & $3.8 \mathrm{bB}$ & $3.1 \mathrm{aA}$ & $3.3 \mathrm{aAB}$ \\
\hline \multirow{2}{*}{$\mathrm{S}$} & \multirow{2}{*}{$166.4^{* *}$} & $173 * *$ & $41 * *$ & 50 & Winter & $2.1 \mathrm{bC}$ & $2.0 \mathrm{bBC}$ & $2.1 \mathrm{bBC}$ & $2.0 \mathrm{bBC}$ & $1.9 \mathrm{bB}$ & $1.6 \mathrm{~A}$ \\
\hline & & $1 / .3^{3}$ & $4.1^{*}$ & 5.0 & Summer & $1.7 \mathrm{aB}$ & $1.6 \mathrm{aB}$ & $1.7 \mathrm{aB}$ & $1.6 \mathrm{aB}$ & $1.3 \mathrm{aA}$ & $1.5 \mathrm{AB}$ \\
\hline $\mathrm{P}$ & $110 * *$ & $103 * *$ & $36 * *$ & 06 & Winter & $32 \mathrm{BC}$ & $33 \mathrm{bBC}$ & $29 \mathrm{AB}$ & $27 \mathrm{AB}$ & $22 \mathrm{~A}$ & $29 \mathrm{bBC}$ \\
\hline B & $11.0^{0.6}$ & $10.3^{3}$ & 0.0 & 9.0 & Summer & $30 \mathrm{C}$ & $27 \mathrm{aABC}$ & $27 \mathrm{ABC}$ & $29 \mathrm{BC}$ & $22 \mathrm{~A}$ & $23 \mathrm{aAB}$ \\
\hline $\mathrm{C}_{\mathrm{s}}$ & 004 ns & $7 *$ & & 70 & Winter & $4.0 \mathrm{aB}$ & $4.2 \mathrm{~B}$ & $4.1 \mathrm{aB}$ & $3.8 \mathrm{aAB}$ & $3.0 \mathrm{~A}$ & $6.0 \mathrm{bC}$ \\
\hline $\mathrm{Cu}$ & 0.04 & 4.1 & 20.1 & 1.9 & Summer & $5.0 \mathrm{bB}$ & $4.7 \mathrm{~B}$ & $5.2 \mathrm{bB}$ & $4.4 \mathrm{bB}$ & $3.0 \mathrm{~A}$ & $3.5 \mathrm{aA}$ \\
\hline E & 111 & & 6 & 72 & Winter & $71 \mathrm{bA}$ & $69 \mathrm{bA}$ & $70 \mathrm{bA}$ & $69 \mathrm{~A}$ & $73 \mathrm{bA}$ & $101 \mathrm{bB}$ \\
\hline re & 111.8 & 17.4 & 0.2 & 1.2 & Summer & $60 a$ & $54 \mathrm{a}$ & $55 \mathrm{a}$ & 62 & $54 a$ & $66 a$ \\
\hline$M$ & & & & 180 & Winter & $156 \mathrm{~A}$ & $162 \mathrm{AB}$ & $262 \mathrm{bBCD}$ & $218 \mathrm{ABC}$ & $287 \mathrm{CD}$ & $343 \mathrm{aD}$ \\
\hline & & & & 10.0 & Summer & $167 \mathrm{~A}$ & $153 \mathrm{~A}$ & $157 \mathrm{aA}$ & $172 \mathrm{~A}$ & $288 \mathrm{~B}$ & $433 \mathrm{bC}$ \\
\hline $7 n$ & $001^{\text {ns }}$ & 52** & $2 * *$ & 7 & Winter & $12 \mathrm{AB}$ & $12 \mathrm{AB}$ & $11 \mathrm{aAB}$ & $11 \mathrm{~A}$ & $11 \mathrm{~A}$ & $13 \mathrm{bB}$ \\
\hline & & & & & Summer & $12 \mathrm{BC}$ & $12 \mathrm{BC}$ & $13 b C$ & $12 \mathrm{ABC}$ & $10 \mathrm{~A}$ & $11 \mathrm{aAB}$ \\
\hline
\end{tabular}

${ }^{1}$ Lowercase letters between the seasons and different capital letters differ between the stages by the Tukey test at $\mathrm{p}<0.05$. Where, ${ }^{\text {ns }}, * * * *$ not significant, significant at $\mathrm{p}<0.01$ and 0.05 , respectively. $\mathrm{CV}=$ Coefficient of variation. $\mathrm{g} . \mathrm{Kg}$ for macronutrient; mg.kg for micronutrien

Table 5. Variation of nutrient contents in banana leaves-index 'Grande Naine' banana plant cultivar in two seasons (Winter and Summer).

\begin{tabular}{|c|c|c|c|c|}
\hline \multirow{3}{*}{ Nutrients } & \multirow{2}{*}{\multicolumn{2}{|c|}{ Variation }} & \multicolumn{2}{|c|}{ Season } \\
\hline & & & \multirow{2}{*}{$\frac{\text { Winter }}{\text { (rainy period) }}$} & \multirow{2}{*}{$\frac{\text { Summer }}{\text { (drought period) }}$} \\
\hline & $\mathrm{F}$ & $\mathrm{CV}(\%)$ & & \\
\hline $\mathrm{N}$ & $15.6^{*}$ & 5.1 & $24.9 b$ & $23.3 \mathrm{a}$ \\
\hline $\mathrm{P}$ & $63 * *$ & 5.5 & $1.7 \mathrm{~b}$ & $1.5 \mathrm{a}$ \\
\hline $\mathrm{K}$ & $4.2^{\mathrm{ns}}$ & 5.4 & $32.9 \mathrm{a}$ & $31.7 \mathrm{a}$ \\
\hline $\mathrm{Ca}$ & $136.9 * *$ & 13 & $5.6 \mathrm{a}$ & $9.4 \mathrm{~b}$ \\
\hline $\mathrm{Mg}$ & $8.1^{*}$ & 7.6 & $2.8 \mathrm{a}$ & $3.0 \mathrm{~b}$ \\
\hline $\mathrm{S}$ & $31.3^{* *}$ & 7.2 & $1.75 b$ & $1.52 \mathrm{a}$ \\
\hline B & $14.6^{* *}$ & 12.2 & $17.6 \mathrm{a}$ & $20.6 b$ \\
\hline $\mathrm{Cu}$ & $35.4^{* *}$ & 6.6 & $5.4 \mathrm{~b}$ & $4.7 \mathrm{a}$ \\
\hline $\mathrm{Fe}$ & $19.5 * *$ & 9.0 & $73.4 \mathrm{~b}$ & $64.2 \mathrm{a}$ \\
\hline Mn & $0.5^{\mathrm{ns}}$ & 24.6 & $330 \mathrm{a}$ & $311.4 \mathrm{a}$ \\
\hline $\mathrm{Zn}$ & $58.7^{* *}$ & 7.7 & $14 \mathrm{~b}$ & $11.1 \mathrm{a}$ \\
\hline
\end{tabular}

${ }^{1}$ Lowercase letters between the seasons by the Tukey test at $\mathrm{p}<0.05$. Where, ${ }^{\text {ns }},{ }^{* *},{ }^{*}$ : not significant, significant at $\mathrm{p}<0.01$ and 0.05 , respectively. $\mathrm{CV}=$ Coefficient of variation; $\mathrm{F}=$ variation factor value. $\mathrm{g} . \mathrm{Kg}$ for macronutrient; $\mathrm{mg} . \mathrm{kg}$ for micronutrien 
Table 6. Variation of nutrient contents in banana leaves-index in 'Grande Naine' banana plant cultivar in six stages of collection.

\begin{tabular}{|c|c|c|c|c|c|c|c|c|}
\hline \multirow{2}{*}{ Nutrient } & \multicolumn{2}{|c|}{ Variation } & \multicolumn{6}{|c|}{ Stage $(\mathrm{T})$} \\
\hline & $\mathrm{F}$ & $\mathrm{CV}(\%)$ & 1 & 2 & 3 & 4 & 5 & 6 \\
\hline $\mathrm{N}$ & $3.2 * *$ & 5.1 & $24.8 \mathrm{AB}$ & $25.1 \mathrm{~B}$ & $24.3 \mathrm{AB}$ & $24.1 \mathrm{AB}$ & $23.1 \mathrm{AB}$ & $22.9 \mathrm{~A}$ \\
\hline $\mathrm{P}$ & $6.5^{* *}$ & 5.5 & 1.6AB & $1.7 \mathrm{~B}$ & $1.7 \mathrm{~B}$ & $1.6 \mathrm{AB}$ & $1.5 \mathrm{~A}$ & $1.5 \mathrm{~A}$ \\
\hline K & $9.8^{* *}$ & 5.4 & $32.4 \mathrm{BC}$ & $32.6 \mathrm{BC}$ & $34.9 \mathrm{C}$ & $34.4 \mathrm{C}$ & $31 \mathrm{AB}$ & $29 \mathrm{~A}$ \\
\hline $\mathrm{Ca}$ & $14.5^{* *}$ & 13 & $6 \mathrm{~A}$ & $6.4 \mathrm{~A}$ & $7.2 \mathrm{AB}$ & $7 \mathrm{~A}$ & $8.8 \mathrm{BC}$ & $10 \mathrm{C}$ \\
\hline $\mathrm{Mg}$ & $2.2^{\mathrm{ns}}$ & 7.6 & $2.7 \mathrm{~A}$ & $2.9 \mathrm{~A}$ & $3.1 \mathrm{~A}$ & $2.8 \mathrm{~A}$ & $2.8 \mathrm{~A}$ & $3 \mathrm{~A}$ \\
\hline $\mathrm{S}$ & $2.2^{\mathrm{ns}}$ & 7.2 & $1.5 \mathrm{~A}$ & $1.6 \mathrm{~A}$ & $1.6 \mathrm{~A}$ & $1.6 \mathrm{~A}$ & $1.7 \mathrm{~A}$ & $1.7 \mathrm{~A}$ \\
\hline B & $5.1 * *$ & 12.2 & $21.1 \mathrm{~B}$ & $21.3 \mathrm{~B}$ & $20.2 \mathrm{AB}$ & 18.9AB & $16.7 \mathrm{~A}$ & $16.4 \mathrm{~A}$ \\
\hline $\mathrm{Cu}$ & $22.7^{*}$ & 6.6 & $5.3 \mathrm{BC}$ & $5.9 \mathrm{C}$ & $5.5 \mathrm{BC}$ & $5.1 \mathrm{~B}$ & $4.3 \mathrm{~A}$ & $4.3 \mathrm{~A}$ \\
\hline $\mathrm{Fe}$ & $9.3^{* *}$ & 9.0 & $60.3 \mathrm{~A}$ & $69.6 \mathrm{~A}$ & $67 \mathrm{~A}$ & $67 \mathrm{~A}$ & $63.3 \mathrm{~A}$ & $83.4 \mathrm{~B}$ \\
\hline $\mathrm{Mn}$ & $5.0^{* *}$ & 24.5 & $227 \mathrm{~A}$ & $290.6 \mathrm{AB}$ & $328.4 \mathrm{AB}$ & $270.8 \mathrm{AB}$ & 403B & $405.1 \mathrm{~B}$ \\
\hline $\mathrm{Zn}$ & $2.2^{\mathrm{ns}}$ & 7.7 & $11.6 \mathrm{~A}$ & $12.7 \mathrm{~A}$ & $12.7 \mathrm{~A}$ & $11.6 \mathrm{~A}$ & $12.9 \mathrm{~A}$ & $12.4 \mathrm{~A}$ \\
\hline
\end{tabular}

Different upper case letters differ between the stages by the Tukey test at $\mathrm{p}<0.05$. Where, ${ }^{\text {ns }},{ }^{* *},{ }^{*}$ : not significant, significant at $\mathrm{p}<0.01$ and 0.05 , respectively. $\mathrm{CV}=$ Coefficient of variation. $\mathrm{g} . \mathrm{Kg}$ for macronutrient; $\mathrm{mg} . \mathrm{kg}$ for micronutrien

\section{Conclusions}

For the 'Prata' and 'Grande Naine' banana plants cultivated in the Ribeira Valley (Vale do Ribeira), there is no significant alteration in the leaf content of the diagnostic leaf (f3) when sampling is realized between the emission of the bunch and the time when it is possible to visualize in the inflorescence all the female tiers and fruits, as well as two open male tiers (MEIR standard), allowing expansion of the leaf collection period to evaluate nutritional status.

\section{References}

BATAGLIA, O.C., FURLANI, A.M.C.; TEIXEIRA, J.P.F.; FURLANI, P.R.; GALLO, J.R. Métodos de análise química de plantas. Campinas: Instituto Agronômico, 1983. (Boletim Técnico, 78).

CASTELAN, F.P.; CASTRO-ALVES, V.C.; SARAIVA, L.A.; NASCIMENTO, T.P.; CÁLHAU, M.F.; DIAS, C.T.; CORDENUNSI-LYSENKO, B.R. Natural ecosystem surrounding a conventional banana crop improves plant health and fruit quality. Frontiers in Plant Science, Bethesda, v. 9, p.759, 2018.

COLTRO, L.; KARASKI, T. U. Environmental indicators of banana production in Brazil: Cavendish and Prata varieties. Journal of Cleaner Production, República Checa, v.207, p.363-378. 2019.

FAO - Food and Agriculture Organization of the United Nations. Faostat. Roma, 2018. Disponível em: http:// www.fao.org/faostat/en/\#data/QC/visualize. Acesso em: 01 out. 2018.
FERREIRA, D. F. Sisvar. Versão 5.6. Lavras: UFLA/ DEX, 2015.

FIGUEIREDO, F.D.; MANTOVANI, E.C.; SOARES, A.A.; COSTA, L.C.; RAMOS, M.M.; OLIVEIRA, F.G. Produtividade e qualidade da banana prata anã, influenciada por lâminas de água, cultivada no Norte de Minas Gerais. Revista Brasileira de Engenharia Agrícola e Ambiental, Campina Grande, v.10, n.4, p.798803, 2006.

FORTESCUE, J. A.; TURNER, D.W.; ROMERO, R. Evidence that banana (Musa spp.), a tropical monocotyledon, has a facultative long-day response to photoperiod. Functional Plant Biology, Melbourne, v. 38, p. 867-878, 2011.

GODOY, L.J.G.; GOMES, J.M.; MENDONÇA, J.C. Levantamento nutricional de bananais do Vale do RibeiraSP pela análise foliar. Scientia Agraria, Curitiba, v.12, n.3, p.157-167, 2011.

IBGE - Instituto Brasileiro de Geografia e Estatística. Banco de dados agregados (SIDRA). Produção Agrícola Municipal (PAM). Rio de Janeiro, 2013. Disponível em: http://www.sidra.ibge.gov.br. Acesso em: 01 nov. 2018.

IEA - Instituto de Economia Agricola. Estatística da produção paulista. São Paulo, 2018. Disponível em: http://ciagri.iea.sp.gov.br/nia1/subjetiva.aspx?cod

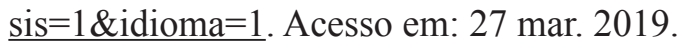


JUllien A.; CHillet, M.; MALÉZIEUX, E. Pre-harvest growth and development, measured as accumulated degree days, determine the post-harvest green life of banana fruit, The Journal of Horticultural Science and Biotechnology, Ashford, v. 83, n. 4, p. 506512. 2008.

MALAVOLTA, E.A. Manual de nutrição mineral de plantas. São Paulo: Agronômica Ceres; 2006.

MARTIN-PRÉVEL P. La nutrition minerale du bananier dans le monde. Fruits, Paris, p.701-751, 1984.

MOREIRA, R.S. Banana: teoria e prática de cultivo. 2.ed. São Paulo: Fundação Cargill, 1987. 335p.

OLIVEIRA, E.M.M.; RUIZ, H.A.; ALVAREZ, V.; HUGO, V.; FERREIRA, P.A., COSTA, F.O.; e ALMEIDA, I.C.C. Nutrient supply by mass flow and diffusion to maize plants in response to soil aggregate size and water potential. Revista Brasileira de Ciência do Solo, Viçosa, MG, v. 34, n. 2, p. 317-328, 2010.

RAIJ, B.V.; ANDRADE, J.C.; CANTARELLA, H.; QUAGGIO, J.A. Análise química para avaliação da fertilidade de solos tropicais. Campinas: IAC, 2001. $285 p$.

RAIJ, B.V.; CANTARELLA, H.; QUAGGIO, J.A.; FURLANI, A.M.C. Recomendações de adubação e calagem para o Estado de São Paulo. Campinas: Instituto Agronômico/Fundação IAC, 1997. p. 285. (Boletim Técnico, 100).
ROBINSON, J.C. Bananas and plantains. Cambridge: CAB International, 1996.

RODRIGUES, M. G. V.; FACHECO, D. D.; NATALE, W.; SILVA, J. T. A. Amostragem foliar da bananeira 'PrataAnã'. Revista Brasileira de Fruticultura, Jaboticabal, v. 32 , n. 1, p. 321-325, 2010.

ROZANE, D. E.; PARENT, L. E.; NATALE, W. Evolution of the predictive criteria for the tropical fruit tree nutritional status. Científica, Jaboticabal, v.44, n.1, p.102-112, 2016.

SILVA, E.B.; RODRIGUES, M.G.V. Levantamento nutricional dos bananais da região norte de Minas Gerais pela análise foliar. Revista Brasileira de Fruticultura, Jaboticabal, v.23, n.3, p. 695-698, 2001.

SILVA, J.T.A.; BORGES, A.L.; MALBURG, J.L. Solos, adubação e nutrição da bananeira. Informe Agropecuário, Belo Horizonte, v.20, n.196, p.21-36, 1999.

TAULYA, G.; ASTEN, P.J.A.; LEFFELAAR, P.A.; GILLER, K.E. Phenological development of East African highland banana involvestrade-offs between physiological age and chronological age. European Journal of Agronomy, Amsterdam, v.60, p.41-53, 2014. 